\title{
GREEN BUILDINGS AND DESIGN FOR ADAPTATION: STRATEGIES FOR RENOVATION OF THE BUILT ENVIRONMENT
}

\author{
A. BOERI, V. GIANFRATE \& D. LONGO \\ Department of Architecture, University of Bologna, Italy.
}

\begin{abstract}
The recent EU Directives 2010/31 and 2012/27 provide standards of nearly zero energy buildings for new constructions, aiming at a better quality of the built environment through the adoption of high-performance solutions. In the near future, cities are expected to be the main engine of development while bearing the impact of population growth: new challenges such as increasing energy efficiency, reducing maintenance costs of buildings and infrastructures, facing the effects of climate change and adjusting on-going and future impacts, require smart and sustainable approaches. To improve the capability of adaptation to dynamics of transformation, buildings and districts have to increase their resilience, assumed as 'the capacity to adapt to changing conditions and to maintain or regain functionality and vitality in the face of stress or disturbance' (Wilson A., Building Resilience in Boston, Boston Society of Architects, 2013). This paper describes the research methodology, developed by the Department of Architecture, a research unit of Technology for Architecture, to perform the assessment of resilience of existing buildings, as well as the outcomes of its application within Bologna urban context. This methodology focuses on the design for adaptation of social housing buildings, aiming at predicting their expected main impacts (energy consumption, emissions, efficiency, urban quality and environmental sustainability) and at developing models for renovation.

Keywords: design for adaptation, green buildings, nZEB technologies, replication potentiality.
\end{abstract}

\section{SPECIFIC CONTEXT}

The Energy Performance of Buildings Directive Recast (EPBD Recast) came into force on 9th July 2010. This directive defines nearly zero energy buildings (nZEB) as a building that has a very high-energy performance and requires the calculation of primary energy indicator. The nearly zero or very low-energy demand should be largely provided by renewable sources, including those produced on-site or nearby. The Member States shall draw up national plans and roadmaps to increase the number of nZEB. A recent benchmarking study on EPBD implementation, carried out by REHVA [1], revealed relevant differences in technical regulations adopted by the EU countries. These differences have a significant effect on the buildings' sector and complicate manufacturing, sales, installation, construction and design of buildings in European Single Market and reduce the pressure to build or renovate according to nZEB standards [2].

The last EU directive 2012/27 faces the challenge to shift to a more energy-efficient economy and to accelerate the spread of innovative technologies, to improve the competitiveness of European industry, to boost economic growth and to create high-quality jobs in several fields related to energy efficiency.

At national level, the transposition of the EPBD directive led Member States to introduce more compulsory energy requirements, including existing buildings deep renovation. The common lines forecast the implementation of Energy Performance Certificates for each building segment and the design of appropriate financial instruments (mainly grants) to support the renovation of the existing buildings stock. 


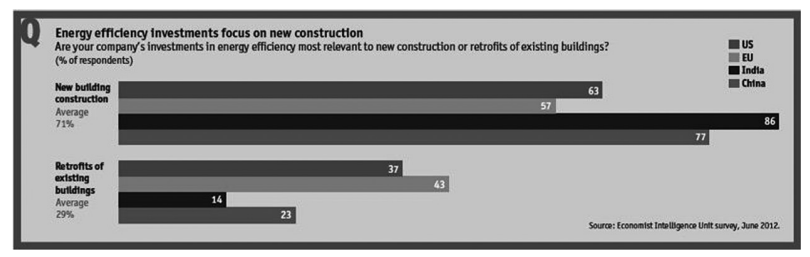

Figure 1: Energy efficiency investments. Source: Economist Intelligence Unit Survey, June 2012.

The reasons to focus on the energy efficiency in existing buildings can be summarized in the following issues related to each point of view and the perspective of society as a whole:

- security of energy supply;

- lower GHG emissions with related effects on climate change strategies;

- reduced energy costs for consumers, which can be important to avoid 'fuel poverty' (where energy costs represent a unequal and unsustainable share of available income) [3];

- increasing energy capacity;

- comfort improvement ;

- relevant contribution to the sustainable development, which is a formal commitment of European countries; and

- improving energy efficiency in buildings, fundamental for the building energy service industries which are important employers in Europe [3] (Fig. 1).

An energy upgrade of the envelope of the building and its equipment, whenever a building is renovated, is a 'win-win' solution related to the EU 2020 Strategy for smart, sustainable and inclusive growth (EC, 2010-a), the EU 2020 and 2030 climate and energy targets (EC, 2014-c), and the EU cohesion policy (EC, 2014-d). It will enhance the prominent role that specialized construction activities already play in terms of value added and employment, while contributing to the EU sustainable growth, climate and energy strategies, and to social and territorial cohesion [4]. From the industry perspective point of view, more mature demand for the renovation of existing buildings would be a valuable stabilizer for the building sector [5].

This paper illustrates the RU studies to speed up the renovation actions addressed to the built environment, based on an integrated approach, inclusive of adaptation strategies at building scale. It describes the methodology applied and the results of a feasibility study carried out on an Italian neighbourhood in Bologna.

\section{DESIGN FOR ADAPTATION}

Cities as centres of innovation will be facing a combination of key environmental and socio-economic drivers of change over the next 40 years which include, besides climate change, rising energy prices, demographic change, increasing densification, social inclusion, information technology and global competitiveness [6]. At the European level, the concept of 'Integrated Sustainable Urban Development' (ISUD) is designed to underpin the Lisbon Strategy for Growth and Jobs, and it has become a cornerstone of the Leipzig Charter on Sustainable European Cities: it is articulated in the following goals: 
- making greater use of integrated urban development policy approaches (by creating and ensuring high-quality public spaces, modernizing infrastructure networks and improving energy efficiency, proactive innovation and educational initiatives);

- paying special attention to disreputable neighbourhoods within the context of the city as a whole (by pursuing strategies to upgrade the physical environment, strengthen the local economy and local labour market policy, instigate proactive education, etc.).

There are a variety of perspectives on the built environment in cities ranging from physical perspectives including form, technologies and materials, geographical and spatial perspectives, socio-economic ones including morphologies and typologies of cities, behavioural issues, lifetime trends, policy and governance perspectives such as the 'urban renaissance' or 'sustainable community topics' [7].

Designing for adaptation is an opportunity to explore new design potentialities and to develop new materials and construction methods to address changing climate strategies. Researches on energy efficient design and construction have produced stunning progresses over recent years, resulting in more attention paid to how homes will operate under varying climate conditions [8]. However, lots of these researches focus on newly constructed homes, whereas widespread application of energy efficient technologies for retrofitting of existing structures needs to be more explored and tested.

The RU is engaged in the development of design for adaptation of existing buildings in the Mediterranean contexts, analysing the most effective and viable solutions, comprehensive of indicators to assess the vulnerability and adaptive capacity of the built environment.

In the Mediterranean area, hot summer conditions influence the design of buildings. Recent heat waves have shown the inadequacy of many of Mediterranean basin building stock in dealing with even higher outdoor temperatures.

A study conducted by CIBSE and Arup investigated how typical existing buildings would cope with future rising summer temperatures. This research has shown that existing buildings are already failing to meet the comfort criteria $\left(25^{\circ} \mathrm{C}\right.$ and $\left.28^{\circ} \mathrm{C}\right)$ and especially those built in the 1960s. The study has highlighted that as the century progresses and external temperatures rise, summertime comfort would decrease further and further [9].

Many parameters play an important role, as the indoor environmental performance of buildings is determined by:

- the general outdoor environmental parameters, which can be locally different due to the microclimate around the building (e.g. sheltered by surrounding buildings and trees);

- the building envelope;

- the building systems (heating, ventilation and air-conditioning - HVAC);

- user behaviour and social conditions (i.e. fuel poverty).

Adaptation to climate change at the building scale has to focus on each of these four aspects.

The Research Unit is involved in a number of research programs and activities concerning the study of renovation processes and the development of appropriate design criteria and strategies aimed at fulfilling the standards and requirements of the recent EU Directives and complying with the highest standards of energy efficiency, climate adaptation, comfort and well-being.

Even if each intervention has its own specific feature and requires suitable tools and strategies, this paper focuses on the common elements that can be methodologically identified to 
overcome recurring barriers that generally affect renovation processes illustrating a case study and related design strategies applied. The main objective is to pinpoint the most suitable and adaptable solutions to be adopted and shared in order to meet the required saving targets.

The developed methodology follows a multidisciplinary analysis, with the aim to combine different sets of intervention strategies and assess their effectiveness under different points of view.

The first stage of the process (the case study modelling) focuses on a clear picture of the current conditions of the buildings, the pathologies affecting it and the deficit to be addressed to. A starting condition level can be defined and used for comparing the results and effects of each retrofitting measures. The second stage is devoted to defining expected lifespan after intervention, according to the age of the building and its starting conditions. A step-by-step retrofitting methodology can be next tested on the model: several implementation options can be carried out, obtaining energy savings in relation to the specific refurbishment strategies selected and applied in each step. When the different steps are set, the results can be compared and discussed to combine different solutions and to select in a holistic way the most suitable and effective ones that will be developed and designed in details before the construction process takes place [10].

This methodological approach, thought for existing buildings, is developed according to an energy concept related to morphological, functional and technological features to optimize the thermal and energy behaviour with reference to different contexts and climatic conditions, with a special focus on building envelope.

\subsection{Climate change and building envelope}

The building envelope is under an intense process of specialization involving all its elements: the improved performances of most of the materials and components need a customized and more effective design of each technical configuration in which they are applied, with positive potential effects on the whole building quality. The 'open' systems of building components, as developed in the 1970s to replace the 'closed' systems, which characterized the first approach to industrialization, are now articulated in sets of high-specialized components and subcomponents, with a large range of applications [11].

New regulation constraints, emerging trends in real estate markets, changing in end-users lifestyles need to develop suitable construction systems, able to meet these new requirements through a deep innovation of their performances, in terms of both product and process.

Increasing thermal comfort and reducing energy use are two key functions of the building envelope and must be considered in conjunction so that ensuring performance in one respect does not compromise performance in the other. As external urban environments become warmer, more work will be required to deal with not only envelope performance in hot conditions but also the connected effect on external urban environments [12] (Fig. 2).

nZEB technology [13] or packages of technologies aim to improve the building energy performance in order to fulfil the national nZEB requirements [14]. These include a large range of techniques, such as better insulation and air-tightness of the building envelope, replacing or improving windows, applying sun screens, installing PV and thermal solar panels, efficient electrical devices and appliances, high-performance HVAC systems, exploiting RES as much as possible.

The following advanced options are needed to improve the energy efficiency of each component, with an approach that considers the building as a whole: 


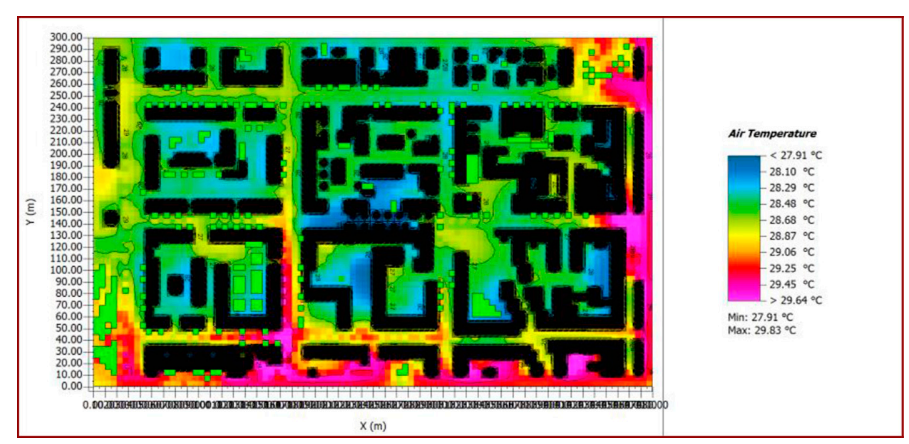

Figure 2: Study of the air temperature in Bolognina Neighbourood (Bologna) (11:00 a.m. of 31st July) elaborated with Envimet Software.

- high levels of insulation in cold climates, applied in walls, roofs and floors to reduce heat losses, with a cost and time-effectiveness perspective;

- high-performance windows, with low thermal transmittance of the entire component (including frames and edge seals) and climate-appropriate solar heat gain coefficients (SHGC);

- high-reflective surfaces in hot climates, including both white and 'cool-coloured' roofs and walls, with glare minimized;

- properly sealed structures to ensure low air infiltration rates, with controlled ventilation;

- minimization of thermal bridges in fasteners and structural components, managing moisture within integrated building components and materials.

The improvement of building envelope performances plays a crucial role in reaching nZEB standard, boostering the adoption of high efficient solutions and techniques.

Considering the strategies to adapt the building envelope to future climate change, the durability and adaptability of the facades are important aspects to consider. To reduce the waste production during the construction and renovation phases, it is important to choose materials and products considering their longevity (almost 25 years) and design facade elements to replace or disassemble by adopting generic connections to facilitate possible future upgrade of the façade [15].

The implementation of the building envelope is usually persued in order to prevent or reduce thermal dispersions that strongly contribute to the total energy demand for heating and cooling. New insulated claddings or additional insulation layers on the outside of the envelope (10-20 cm thick) represent the most viable and effective solution to prevent deficits related to thermal bridges that usually affect the building stock, object of renovation.

\subsubsection{Modular preassembled system for the building envelope renovation}

Compared to traditional construction processes, preassembled systems aim at reducing costs without compromising quality and facilitating installation/dismantling/re-use of components. Building components prefabricated in factories gain allow to save time in construction and to improve on-site health and safety. The fast work-on-site for installation is particularly suitable for renovation, considering that the buildings to be renovated are often occupied. Prefabricated techniques should be adaptable to individual renovation solutions and should allow to produce better performing products. Innovative technologies for 
energy efficiency (e.g. HVAC components) and renewable energy sources (e.g. photovoltaic, solar collectors, etc.) can also be integrated in the prefabricated multi-functional modules and components [16].

Preassembled modules are built in factory, shipped to the site, installed here and assembled to create a complete building. Faster speed of construction and - thus - faster return on the investments are some of the major drivers for the spread of this type of construction, which includes a variety of typologies, from single-house to high-rise with different functions, including residential, student housing, public buildings and commercial ones [17]. Other benefits consist in more safe and productive working conditions in the manufacturing sector, which is of particular value in extreme climate regions, as well as benefits in transportation and logistics: modules to be transported and installed, and the structural capability of the final product needs to be carefully considered in the design of modular buildings.

A study dated 2007 indicates that to perform a cost-effective modular construction, the following strategies are required [18]:

- complete mechanization of the production process;

- elimination of the amount of site work required as much as possible; and

- maximization of the usage of recycled materials for prefabricated building components.

Preassembled practice, compared to traditional ones, aims at reducing costs for the same quality levels and facilitates the installation/dismantling/re-use of components. It also facilitates the re-use of components from both the construction and industrial sectors.

A research program, carried out by the research group of Technology for Architecture from the University of Bologna (UNIBO) - Department of Architecture (DA), adopts a holistic approach for integrated design process, focusing on:

- the optimization of building envelope behaviour for residential multi-dwellings during summer period in the Mediterranean area, using a simulation model to test new materials and components and assess the possible integration of structure and equipment [19];

- the definition of a comparative assessment of the building envelope performances in relation to different technical configurations, in terms of U-value, thermal phase displacement, thermal mass, $\mathrm{CO}_{2}$ emissions related impact of the building energy consumption, and smart integration of structure, equipment and services, including RES installations.

This research aims at analysing the materials and components behaviour in the entire life cycle of buildings and, consequently, checking the best performance of the envelope products, taking into account important aspects, such as the overall thermal performance and airtightness. This study investigates the right strategies to limit operation costs and facilitate the building integration processes, considering the challenge of aesthetic factor for existing buildings.

The research of the UNIBO-DA recognizes the housing industry inefficiencies and fragmentation related to the slow adoption of new technologies [20] and promotes a shift of paradigm for the construction sector that uses industrialized manufacturing models and technology transfer in the design and procurement process, based on final climatic and environmental performance.

The overarching objective of this research is to create a new way to conceptualize technological innovative housing design for adaptation that integrates environmental and economic sustainability [21], focusing on: 
- creating advantages for construction using factory-based manufacturing methods;

- innovating construction concepts using entirely pre-assembled modular components; and

_ integrating low-energy/whole-house design and sustainable technologies.

Quantifying and evaluating dynamic energy performances of opaque envelope in hot climate is a crucial and common field of investigation at international level. Studies and researches underline the importance of summer thermal conditions control, through the adoption of an appropriate layered envelopes with a specific combination and position of construction materials (using in the same stratigraphy both standard and innovative materials).

Studies and simulations investigated innovative and high-performance materials, components and systems available on the market classified as green. The purpose was to check the features of these new technologies and their performances, simulating their behaviour on a range of pilot cases of buildings. The design brief for the demonstration project focused on the use of modular systems to increase quality without increasing initial construction costs, adopting the following main strategies:

- standardization of components (i.e. reiteration of component and joint details);

- reduction of the number of joints to increase onsite craftsmanship;

- reduction in numbers and weight of components to be transported; and

- minimization of the amount and the complexity of work done onsite (foundation prework and onsite preassembly).

The challenge is to adopt and integrate (in some case with a replacement of portion of facades) these systems in the envelopes of existing buildings, where geometrical and morphological features - such as cantilevered elements, lodges, terraces, etc. - represent significant constraints in defining the most effective solution that can provide a continuous thermal wrap of the whole envelope. In addition to this, a number of regulations (concerning the shape and volume of the building as well as the level of protection in case of historical buildings) represent the second main technical barrier. Amongst the non-technical barriers, the most influencing factors are the ones connected to the property and the related chance to apply the solutions to the overall surface of the building envelope in order to obtain an effective kind of intervention. This can influence also the management of construction site and the duration of intervention. A very strong decisional barrier to the achievement of the expected results is represented by fragmented property, which characterized a large part of the building stock, especially in Italy, where the pilot cases were conducted.

\section{THE PILOT: A FEASIBILITY STUDY FOR BOLOGNA NEIGHBOURHOOD}

The technical and non-technical barriers described before were taken into consideration in the development of the feasibility study for a neighbourhood located in Bologna, in the North of Italy. This study was carried out by the Research Unit of Technology for Architecture of the Department of Architecture in cooperation with the Municipality of Bologna and ACER, the Regional Estate Agency. This study is considered as a first step for further experimentation at urban level, testing the methodology and effectiveness of technical and financial solutions for an nZEB district regeneration in Bologna urban and climatic context (Table 1).

This initiative is connected with Rigenera Program, leaded by the Municipality of Bologna (SEAP - Sustainability Energy Action Plan) in collaboration with ACER, to renovate 23 
Table 1: Climatic data of Bologna.

\begin{tabular}{ll}
\hline Latitude & $44^{\circ} 30^{\prime} 27^{\prime} \mathrm{N}$ \\
Longitude & $11^{\circ} 21^{\prime} 5^{\prime \prime} \mathrm{E}$ \\
Elevation & $54 \mathrm{~m}$ \\
Degree days & 2259 \\
Climatic zone & $\mathrm{E}$ \\
\hline
\end{tabular}

social residential buildings blocks, selected to represent widespread typologies in the city context. The Municipality and ACER will support the retrofitting and refurbishment of these building blocks with different investments in terms of energy efficiency and implementation/ improvement of the heating systems.

A consistent group of buildings with Social Housing destination are located in the Bolognina District (Figs 3 and 4), and represents, for typology, age of construction, technological features, an interesting test bench for the application and replicability of nZEB technologies at district scale.

The research unit selected three buildings in this district (Table 2), following several indicators, such as: availability of data (about energy and architectural issues), total public property, typology, location in the neighbourhood, and replication potentiality.

Many factors influence cost-effectiveness of investments in boosting the energy efficiency at buildings and district levels: refurbishment costs, future energy prices, attainable rents, borrowing rates, condition and age of the building as well as a number of other factors.

Following a multi-dimensional approach for systematic renovation and improvement of buildings and district elements, the RU aims at identifying cost-effective solutions based on a substantial energy demand reduction but with a more ambitious perspective.

The design for adaptation applied to the case studies envisages:

- to establish performance targets for each demo-site, based on key-performance indicators, and develop preliminary strategies to achieve these targets in these specific demonstrators (Table 3);

- to define cost-effective retrofitting strategies (comparing retrofitting costs and energy lifetime costs to find the optimum value) through efficient building envelope, application of technologies for refurbishment, and careful selection of materials (Table 4);

- to analyse how to meet heating and cooling loads through the maximum use of renewable technologies, available waste heat sources and of efficient HVAC systems (including already existing systems), while maintaining performance targets for indoor air quality, thermal comfort, etc.;

- to repeat the process to produce at least two, and preferably three, concept design alternatives, and then select and apply the most promising one for the development of the demonstration.

The design strategy adopted has been developed according to the following indicators (Tables 5 and 6):

- low cost/cost-effective solutions aiming at high standards of quality and energy efficiency, both during construction and management phases. The adoption of assembled construc- 


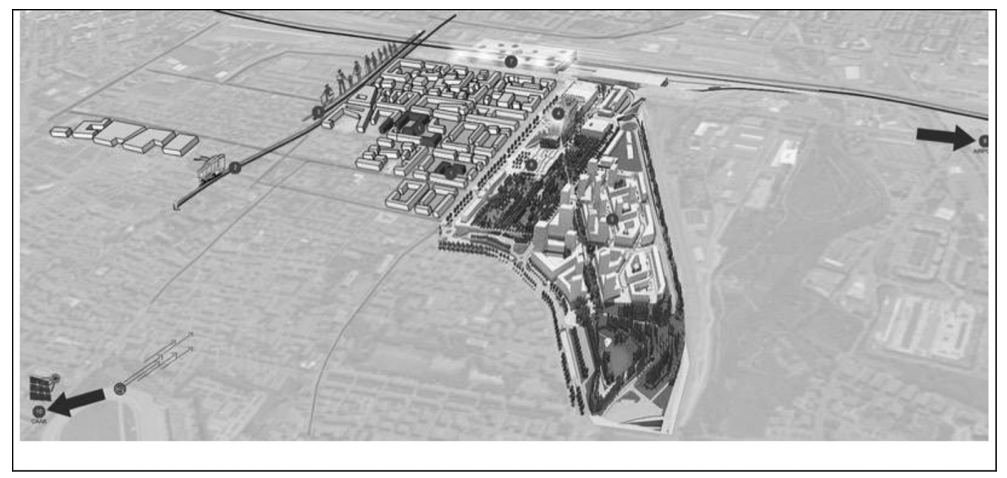

Figure 3: Panoramic view of the interventions in Bolognina urban context.

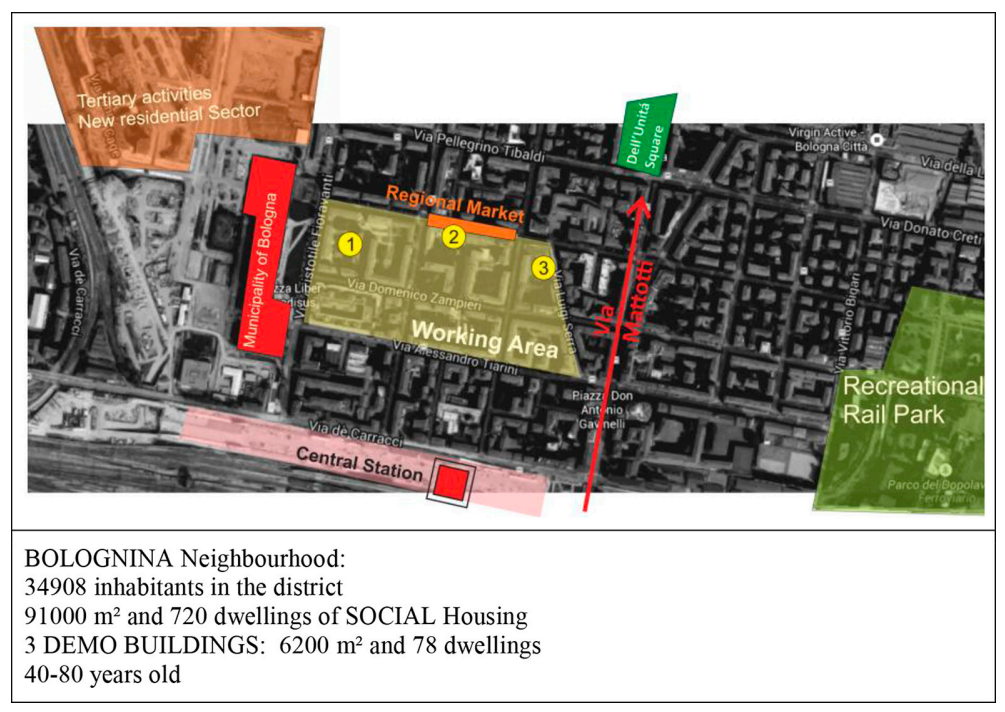

Figure 4: Bolognina working area. Bolognina Neighbourhood: 34,908 inhabitants in the district; $91,000 \mathrm{~m}^{2}$ and 720 dwellings of social housing; 3 demo buildings: $6200 \mathrm{~m}^{2}$ and 78 dwellings. $40-80$ years old.

tion systems and durable - easy to maintain - materials plays a key role. Furthermore, the selected materials are expected to satisfy a service life of 50 years (according to the literature), in order to enlarge maintenance intervals [22];

- fast work-on-site, with the adoption of an integrated design process as well as of standardized assembled construction systems with the aim of reducing the construction time and costs [23];

- limited disruption for the end-users ( $1 / 3$ days as construction time), thanks to the adoption of standardized assembled construction systems, assumed as a key-element to deliver the renovation in this specific socio-economic context. Customizable solutions, to be adapted in different geographical and economic contexts, allow to optimize the construction process and the potential benefit for the customer; 
Table 2: Trial buildings: characteristics and performance.

\begin{tabular}{|c|c|c|}
\hline \multicolumn{3}{|c|}{ Building 1. Historic building via Tibaldi 42} \\
\hline & $\begin{array}{l}\text { Year of } \\
\text { construction }\end{array}$ & 1928 \\
\hline & Typology & $\begin{array}{l}\text { Building in the courtyard surrounded by } \\
\text { other similar } 5 \text { buildings }\end{array}$ \\
\hline & No. of flats & 15 \\
\hline & No. of inhabitants & 42 people ( 9 old people, 26 foreign people) \\
\hline & Dimension & total $1200 \mathrm{~m}^{2}\left(70 \mathrm{~m}^{2} / \mathrm{flat}\right)$ \\
\hline & Performance & $276,10 \mathrm{KWhm}^{2} /$ year of energy consumption \\
\hline \multicolumn{3}{|c|}{ Building 2. 1960s building via Albani 16} \\
\hline & $\begin{array}{l}\text { Year of } \\
\text { construction }\end{array}$ & 1954 \\
\hline & Typology & $\begin{array}{l}\text { 'L' configuration building at the corner of } \\
\text { two traffic congested streets, overlooking a } \\
\text { courtyard }\end{array}$ \\
\hline & No. of flats & 42 \\
\hline & No. of inhabitants & 115 (17 old people, 70 foreign people) \\
\hline & Dimension & total of $3070 \mathrm{~m}^{2}\left(60 / 70 \mathrm{~m}^{2} / \mathrm{flat}\right)$ \\
\hline & Performance & $312,37 \mathrm{KWhm}^{2} /$ year of energy consumption \\
\hline \multicolumn{3}{|c|}{ Building 3. 1950s building via Di Vincenzo 27} \\
\hline & $\begin{array}{l}\text { Year of } \\
\text { construction }\end{array}$ & 1948 \\
\hline & Typology & In-line building overlooking a courtyard \\
\hline & No. of flats & 24 \\
\hline 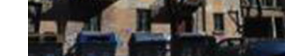 & No. of inhabitants & 52 (15 old people, 21 foreign people) \\
\hline & Dimension & total of $2000 \mathrm{~m}^{2}\left(70 / 80 \mathrm{~m}^{2} / \mathrm{flat}\right)$ \\
\hline & Performance & $224,62 \mathrm{KWhm}^{2} /$ year of energy consumption \\
\hline
\end{tabular}

- improvement of the building performance with the optimization of the thermal features of the building envelope (Fig. 4) for the achievement of high performance both in winter and in summer conditions. In the winter time, high level of performances is achieved by adopting different insulation layers according to the orientation of the building envelope. Remarkable results are achieved, thanks to the application of wood windows frame integrating aerogel panels (produced by a local company), which allows to reduce the frame section (saving material and resources) while maximizing cost-effectiveness.

Overheating during summer time has been reduced adopting a ventilated cladding, installed over the existing envelope, in particular on south and west facades. The ventilation cavity provides a 'Venturi' effect to extract warm air from the façade while the mass of the wall 
Table 3: Performances of the envelope.

\begin{tabular}{|c|c|c|c|c|c|}
\hline \multirow{2}{*}{$\begin{array}{l}\text { Building fabric } \\
\text { Façade/wall } \mathrm{U}\left(\mathrm{W} / \mathrm{m}^{2} \mathrm{~K}\right)\end{array}$} & \multirow{2}{*}{$\begin{array}{r}\text { Existing } \\
\text { building } \\
\\
1.60\end{array}$} & \multirow{2}{*}{$\begin{array}{l}\text { National } \\
\text { regulation for } \\
\text { refurbished } \\
\text { buildings }\end{array}$} & \multicolumn{2}{|c|}{$\begin{array}{c}\text { Project } \\
\text { performances }\end{array}$} & \multirow{2}{*}{$\begin{array}{c}\begin{array}{c}\text { Reduction } \\
\text { related to } \\
\text { national } \\
\text { regulation \% }\end{array} \\
31\end{array}$} \\
\hline & & & B1 & 0.23 & \\
\hline & & & B2 & 0.19 & 44 \\
\hline & & & B3 & 0.19 & 44 \\
\hline \multirow[t]{3}{*}{ Roof U (W/m² K) } & 1.60 & 0.30 & B1 & 0.19 & 37 \\
\hline & & & B2 & 0.19 & 37 \\
\hline & & & B3 & 0.19 & 37 \\
\hline \multirow[t]{3}{*}{ Ground floor $\mathrm{U}\left(\mathrm{W} / \mathrm{m}^{2} \mathrm{~K}\right)$} & 1.40 & 0.33 & B1 & 0.25 & 24 \\
\hline & & & B2 & 0.25 & 24 \\
\hline & & & B3 & 0.33 & 0 \\
\hline \multirow[t]{3}{*}{ Glazing $\mathrm{U}_{\mathrm{g}}\left(\mathrm{W} / \mathrm{m}^{2} \mathrm{~K}\right)$} & 4.00 & 1.70 & B1 & 1.20 & 33 \\
\hline & & & B2 & 1.20 & 33 \\
\hline & & & B3 & 1.20 & 33 \\
\hline \multirow{3}{*}{$\begin{array}{l}\text { Average U-value } \\
\mathrm{U}_{\mathrm{g}}\left(\mathrm{W} / \mathrm{m}^{2} \mathrm{~K}\right)\end{array}$} & 2.15 & 0.67 & B1 & 0.47 & 30 \\
\hline & & & B2 & 0.46 & 31 \\
\hline & & & B3 & 0.46 & 31 \\
\hline
\end{tabular}

ensures an adequate thermal lag and temperature dumping. High performance glazed elements avoid dispersions. Advanced methodologies for integration and controlled junction systems between windows and wall are essential to ensure adequate air tightness;

- home automation system integration to increase the level of energy efficiency by integrating ICT sensors and devices to control, manage and monitor equipment according to a 'smart' concept;

- fuel poverty reduction with the integrated programme for RES exploitation. Preliminary estimations of the efficiency have been considered as well as the potential update of the adopted solution;

- high replicability of solutions in order to ensure the scalability of interventions: the adopted solution are thought to maximize the cost effectiveness and to reduce the construction timeframe, facilitating the revenue of the investment;

- environmental performance according to lifecycle analysis (LCA) [24].

This aimed to encourage the adoption of materials with a limited embodied energy, recyclable and with limited impact during production chain, construction phase and end service life.

The envisaged solutions integrate active solar gains (PV and solar collectors) into buildings, which are assumed as 'prosumers' [25] (production + consumption), transforming very conventional and energy consuming volumes into efficient nodes of an integrated smart grid. 
Table 4: Technical solutions.

\begin{tabular}{|c|c|c|c|}
\hline \multicolumn{4}{|l|}{ Building 1 (B1) } \\
\hline Technical solution & Quantity & Cost $/ \mathrm{m}^{2}$ & Total cost \\
\hline $\begin{array}{l}\text { A: Internal insulation with polystyrene panels: } \\
\quad-14 \mathrm{~cm} \\
\quad-\lambda=0.031 \mathrm{~W} / \mathrm{mK}\end{array}$ & $1800 \mathrm{~m}^{2}$ & $60 € / \mathrm{m}^{2}$ & $108,000 €$ \\
\hline $\begin{array}{l}\text { B: Replacement of windows: } \\
\quad-\text { wood-frame } \\
\quad-\mathrm{U}=1.2 \mathrm{~W} / \mathrm{m} 2 \mathrm{~K} \\
\quad-\text { losses for ventilation }=1.4 \mathrm{~m}^{3} / \mathrm{hm}^{2} \\
\quad-\text { connection with domotic systems }\end{array}$ & $207,68 \mathrm{~m}^{2}$ & $800 € / \mathrm{m}^{2}$ & $166,144 €$ \\
\hline $\begin{array}{l}\text { C: Replacement of decentralized boilers with } \\
\text { condensing ones }\end{array}$ & 15 units & $4000 € /$ unit & $60,000 €$ \\
\hline D: Solar thermal panels & 15 units & $3000 € /$ unit & $45,000 €$ \\
\hline \multicolumn{4}{|c|}{ Total costs for retrofitting $379,144 €\left(315,95 € / \mathrm{m}^{2}\right)$} \\
\hline \multicolumn{4}{|l|}{ Building 2 (B2) } \\
\hline $\begin{array}{l}\text { A: External insulation with polystyrene panels: } \\
\quad-14 \mathrm{~cm} \\
\quad-\lambda=0.031 \mathrm{~W} / \mathrm{mK}\end{array}$ & $2018 \mathrm{~m}^{2}$ & $60 € / \mathrm{m}^{2}$ & $121,080 €$ \\
\hline $\begin{array}{l}\text { B: Ventilated façade with porcelain stoneware } \\
\text { slabs }\end{array}$ & $774 \mathrm{~m}^{2}$ & $250 € / \mathrm{m}^{2}$ & $193,500 €$ \\
\hline C: Experimental green façade & $162 \mathrm{~m}^{2}$ & $180 € / \mathrm{m}^{2}$ & $29,160 €$ \\
\hline $\begin{array}{l}\text { D: Replacement of windows } \\
\qquad \begin{aligned} & - \text { wood-frame } \\
& -\mathrm{U}=1.2 \mathrm{~W} / \mathrm{m}^{2} \mathrm{~K} \\
& - \text { losses for ventilation }=1.4 \mathrm{~m}^{3} / \mathrm{hm}^{2} \\
& - \text { connection with domotic systems }\end{aligned}\end{array}$ & $464 \mathrm{~m}^{2}$ & $800 € / \mathrm{m}^{2}$ & $371,344 €$ \\
\hline $\begin{array}{l}\text { E: Replacement of decentralized boilers with } \\
\text { centralized and condensing one of } 75 \mathrm{~kW}\end{array}$ & 40 units & $4000 € /$ unit & $160,000 €$ \\
\hline F: Solar thermal panels & 40 units & $3000 € /$ unit & $120,000 €$ \\
\hline G: PV panels & $250 \mathrm{~m}^{2}$ & & \\
\hline Total costs for retrofitting $995,084 €\left(324,13 € / \mathrm{m}^{2}\right)$ & & & \\
\hline
\end{tabular}




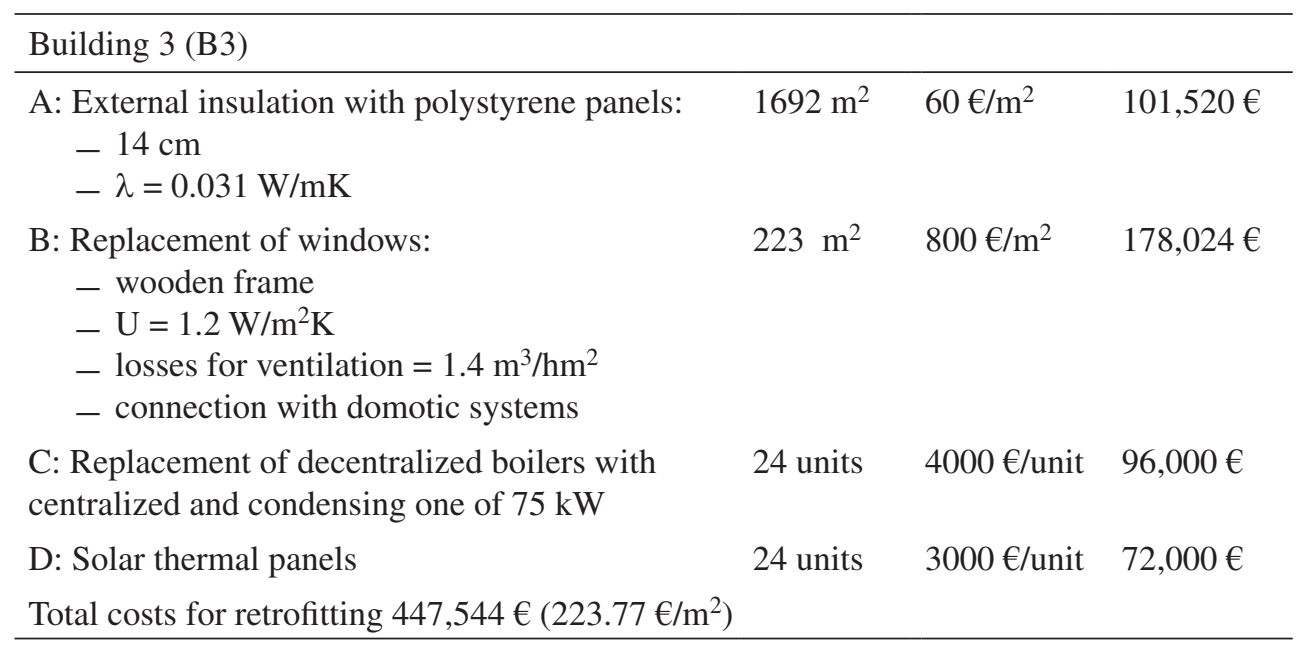

The mitigation of climate conditions (UHI effects) is a key part of the refurbishment strategy: the envisaged solutions aimed at increasing indoor and outdoor comfort conditions by adopting facade components (green integration, solar collectors/DSSC panels) as shading systems and thermal regulators. The substructure of these functional elements are used to support the vegetation and obtain a mitigation effect to the risk of overheating during summer time, improving also the building behaviour against more frequent extreme weather conditions.

\section{LESSON LEARNED AND FUTURE RESEARCH DIRECTIONS}

Bologna feasibility study is mostly addressed to Social Housing areas that currently provide 11,889 ERP dwellings in different districts of the city. Built during the post WII expansion, this building stock requires a comprehensive renovation strategy capable of increasing energy performance, improving living quality and comfort conditions, but - above all - integrating the district and its community into a sustainable and low-carbon city vision.

The huge number and peculiar typology of this building stock as well as the limited resources available, require a coherent, articulated and replicable strategy ensuring the financial feasibility in a reasonable timeframe with a limited disruption for the end-users.

The focus on social housing sector with public property is faced with particular attention to the cost-effective renovation activities, and the study forecasts different strategies to achieve it, like:

- the integration of systems that leads to the integration of components;

- the re-design of components and renovation concepts for industrial assembling of them to reduce the amount of materials used and waste, time and costs;

- the development of smart Plug \& Play connectors for quick and easy installation (in accordance with the SMEs involved in the project);

- the re-design of integrated, industrial, cost-efficient, sustainable and demand-driven products;

- the scaling up of the solutions for renovation, with flexible and adaptable approach;

- the identification of technical solution to minimize intervention in flats.

This study offers viable solutions, using 'green' and healthy approach, aiming at improving resident health and building performances. 
Table 5: Key performance indicators (costs; timing; no disruption) for Bolognina retrofitting solutions.

\begin{tabular}{|c|c|c|c|c|}
\hline \multicolumn{5}{|c|}{ Indicators } \\
\hline \multirow{4}{*}{$\begin{array}{l}\text { Building } \\
\text { elements }\end{array}$} & Solutions & Cost-effectiveness & Fast work-on-site & $\begin{array}{l}\text { Limited disruption } \\
\text { for tenants }\end{array}$ \\
\hline & $\begin{array}{l}\text { Typology and } \\
\text { description }\end{array}$ & $\begin{array}{l}\text { Long service life } \\
\text { of components } \\
\text { and systems. } \\
\text { Short/medium } \\
\text { payback period }\end{array}$ & $\begin{array}{l}\text { Pre-assembled } \\
\text { components. } \\
\text { Lightweight } \\
\text { construction. Low } \\
\text { operational water } \\
\text { use. Open-loop } \\
\text { recycling process }\end{array}$ & $\begin{array}{l}\text { Outside } \\
\text { interventions } \\
\text { Fast assembly of } \\
\text { components. }\end{array}$ \\
\hline & $\begin{array}{l}\text { Building opaque } \\
\text { envelope: } \\
\text { ventilated } \\
\text { facades with } \\
\text { aluminium } \\
\text { structure and } \\
\text { porcelain panels }\end{array}$ & $\begin{array}{l}50 \% \text { costs } \\
\text { savings compared } \\
\text { to a conventional } \\
\text { option (rainscreen } \\
\text { thermal cladding) }\end{array}$ & $\begin{array}{l}\text { Average speed } \\
\left(2000 \mathrm{~m}^{2} / \mathrm{month}\right. \\
\left.=70 \mathrm{~m}^{2} / \text { day }\right)\end{array}$ & $\begin{array}{l}\text { Over-cladding } \\
\text { is applied from } \\
\text { outside: no } \\
\text { disruptions for } \\
\text { tenants }\end{array}$ \\
\hline & $\begin{array}{l}\text { Glazing and } \\
\text { shading system: } \\
\text { windows } \\
\text { advanced } \\
\text { engineering } \\
\text { system equipped } \\
\text { with shading } \\
\text { solutions. } \\
\text { Effective } \\
\text { interface with } \\
\text { opaque elements } \\
\text { of the envelope }\end{array}$ & $\begin{array}{l}40-50 \% \text { cost } \\
\text { savings compared } \\
\text { to a conventional } \\
\text { option }\end{array}$ & $\begin{array}{l}\text { Frame + primary } \\
\text { units } \\
1.5-2 \text { days per } \\
\text { residential unit }\end{array}$ & $\begin{array}{l}\text { Reduction of } \\
\text { on-site operations } \\
\text { time (15\% less } \\
\text { compared to } \\
\text { standard systems) }\end{array}$ \\
\hline
\end{tabular}

Improving the energy efficiency of residential buildings is critical in addressing the global energy challenge. Determining a design for adaptation of existing building stock implies to maximize the thermal and light gains, reduce the construction time and ensure the efficiency of the assembly process. The research outputs can be summarized as reported: optimization of energy performances; automatization of climate control and encouragement of ecologically responsible behaviour. Furthermore, it promotes a construction approach, based on:

- modular design, at each level;

- efficient assembly, disassembly, transportability;

- responsible selection of materials;

- efficient combination of conservative, selective and responsive procedures of intervention; and

- performance-driven design, capable of answering to energy efficiency and climate change challenges. 
Table 6: Key-performance indicators (energy performance, fuel poverty, replication potential, LCA) for Bolognina retrofitting solutions.

\begin{tabular}{|c|c|c|c|c|}
\hline \multicolumn{5}{|c|}{ Indicators } \\
\hline \multirow{4}{*}{$\begin{array}{l}\text { Building } \\
\text { elements }\end{array}$} & $\begin{array}{c}\text { Energy } \\
\text { performance }\end{array}$ & Fuel poverty & Replicability & LCA \\
\hline & $\begin{array}{l}\text { Typology and } \\
\text { description }\end{array}$ & $\begin{array}{l}\text { Locally } \\
\text { sourced } \\
\text { material } \\
\text { Low carbon } \\
\text { technology }\end{array}$ & $\begin{array}{l}\text { Modular } \\
\text { components and } \\
\text { standardization } \\
\text { of elements }\end{array}$ & Building lifecycle information \\
\hline & $\begin{array}{l}\text { Building } \\
\text { opaque } \\
\text { envelope: } \\
\text { ventilated } \\
\text { facades with } \\
\text { aluminium } \\
\text { structure and } \\
\text { porcelain } \\
\text { panels }\end{array}$ & $\begin{array}{l}\text { Improvement } \\
\text { of winter/ } \\
\text { summer } \\
\text { comfort } \\
\text { indoor also } \\
\text { without } \\
\text { heating/ } \\
\text { cooling } \\
\text { systems } \\
\text { limited use }\end{array}$ & $\begin{array}{l}\text { Pre-casted and } \\
\text { layered system }\end{array}$ & 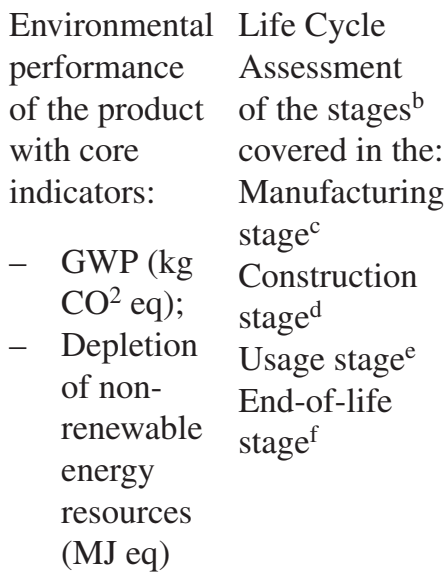 \\
\hline & $\begin{array}{l}\text { Glazing } \\
\text { and shading } \\
\text { system: } \\
\text { windows } \\
\text { advanced } \\
\text { engineering } \\
\text { system } \\
\text { equipped } \\
\text { with shading } \\
\text { solutions. } \\
\text { Effective } \\
\text { interface } \\
\text { with opaque } \\
\text { elements of } \\
\text { the envelope }\end{array}$ & $\begin{array}{l}\text { Improvement } \\
\text { of winter/ } \\
\text { summer } \\
\text { comfort } \\
\text { indoor also } \\
\text { without } \\
\text { heating/ } \\
\text { cooling } \\
\text { systems } \\
\text { limited use }\end{array}$ & $\begin{array}{l}\text { Pre-assembled } \\
\text { windows }\end{array}$ & $\begin{array}{l}\text { FSC and/or } \\
\text { PEFC label } \\
\text { LEED } \\
\text { standard for } \\
\text { VOC low } \\
\text { emissions }\end{array}$ \\
\hline
\end{tabular}

${ }^{\text {a }}$ Silica aerogel into the frame of the window.

${ }^{\mathrm{b}}$ Module approach required by EN 15804 .

${ }^{\mathrm{c}}$ The product stage includes: raw materials extraction and processing, processing of secondary material input (e.g. recycling processes), transport to the manufacturer and manufacturing.

${ }^{\mathrm{d}}$ The construction process stage includes: transport to the building site and installation into the building.

${ }^{\mathrm{e}}$ The use stage related to the building fabric includes: use of application of the installed product, maintenance, repair, replacement, refurbishment, operational energy use and operational water use.

${ }^{f}$ The end-of-life stage includes: de-construction, demolition, transport to waste processing; waste processing for reuse, recovery and/or recycling and disposal. 
Table 7: Results of the demonstration activities.

\begin{tabular}{lrl}
\hline $\mathrm{m}^{2}$ total of heating surfaces & 5427 & $\mathrm{~m}^{2}$ \\
& 1720 & Building 1 \\
2702 & Building 2 \\
& 1005 & Building 3 \\
Sum of energy savings (improvement of national & 263.04 & $\mathrm{kWh} / \mathrm{m}^{2} \mathrm{y}$ \\
regulation) & 75.60 & Building 1 \\
& 79.59 & Building 2 \\
& 72.47 & Building 3 \\
Sum of RES contribution (improvement of national & 17.69 & $\mathrm{kWh} / \mathrm{m}^{2} \mathrm{y}$ \\
regulation) & 2.79 & Building 1 \\
& 4.64 & Building 2 \\
& 10.26 & Building 3 \\
Sum of $\mathrm{CO}_{2}$ savings & 229,659 & $\mathrm{~kg}$ \\
& 62,559 & Building 1 \\
& 125,590 & Building 2 \\
& 41,470 & Building 3 \\
\hline
\end{tabular}

This feasibility study demonstrates that the adoption of the application of the methodology pointed up by the RU could produce energy savings of $265 \mathrm{kWh} / \mathrm{m}^{2}$ per year and $\mathrm{CO}_{2}$ savings of 230 ton per year, with substantial costs reduction in management of public buildings stock for Public Administrations (as shown in Table 7).

The technologies and integrated systems adopted allow to significantly overpass the national regulation limits for the refurbishment of existing buildings, obtaining an improvement of energy performance of the trial buildings, and a reduction of transmittance value between $60 \%$ and $80 \%$.

These positive results have a great impact, furnishing to the Municipality of Bologna and to ACER success examples for an effective refurbishment in terms of costs and fast work-onsite, with a very limited disruption for end-users (between 1 day to a week).

The three case studies are representative of the most of the social housing stock in Bologna city area and in the Emilia Romagna region (in terms of age of construction, materials and techniques adopted, etc.); therefore, the studied solutions have a great potential of replicability:

- the city centre houses 783 social housing buildings (11,889 flats and 25,575 people);

- in Bologna Metropolitan area there are 1676 social housing buildings (18,461 flats), with a $38 \%$ of constructions built before 1960;

- the total amount of social housing buildings of Emilia Romagna Region is 6,499.

The Municipality of Bologna is currently taken a multi-level approach, promoting a combination of mandatory upgrades, incentive programmes, funding incentives and education/ outreach programs to develop more resilient building stock. 
Neighbourhoods like Bolognina district, which was settled over 100 years ago, a critical aspect related to resilience potentiality consists in adapting existing buildings to climate change impacts.

The feasibility study, following a step-by-step process, includes both targeted or incremental improvements that can be implemented over time and widespread or major improvements that can require significant investments and coordination with building occupants.

Bolognina project objective is to provide a technical plan for the block houses aimed at increasing performances of the buildings, reducing environmental impact (GHG emissions), controlling the value of apartments, generating incomes (through lower energy bills), alleviating fuel poverty and creating job positions linked with renovation at local scale. It is crucial to create the right conditions, like:

- delivering retrofits that result in the highest long-term levels of customer satisfaction;

- commercial opportunities arising from the role of energy advice within low carbon retrofit; and

- managing the expectations of residents.

In the meantime, it is necessary to explore perceptions and raise awareness towards energy relevant technologies of targeted stakeholder groups in the energy system, including energy end-users. The final goal is the acceptance and diffusion of low-carbon and energy technologies in the retrofitting actions.

Generally speaking, tenants should be expected to benefit from low carbon retrofitting, thanks to:

- lower fuel bills;

- more comfortable homes;

- improvements to their health;

- awareness they have reduced on their home's impact on the environment.

In the next steps of the research, the RU will take into account the engagement of citizens and tenants of the neighbourhood to build up consensus on the project and implement a process of citizens democratic participation to its realization. This will be the occasion to introduce a co-design approach to implement the acceptance of low-carbon technologies in this renovation action.

The future branch forecasts the application of the feasibility study on the three trial buildings with a monitoring phase to test the effectiveness in the short term and in the medium term of the outcomes of the demonstration. This experimental action will integrate the current Rigenera project, and it will offer a more comprehensive and replicable strategy of intervention in Bologna urban context, including timing and costs of this initiative.

Another crucial point is the implementation of climate adaptation strategies into the regulatory framework of the city, with a special focus on existing buildings. Building regulations need a holistic review in the context of climate change adaptation; they have an important role to play in preparing urban settlements for a safe and sustainable future. An appropriate policy mix will be required to deliver climate adapted and resilient buildings to cope with these impacts. Existing buildings can be made climate resilient by ensuring adaptation as an integral part of the housing stock upgrade process [26]. 
The RU will support this implementation in collaboration with the Municipality of Bologna, extending its 'design for adaptation' studies, with:

- a more detailed analysis of how the nature of the climate change (e.g. changes in solar irradiance vs. changes in dry-bulb temperature) affects the optimal $g$-value of Bologna context;

- integration with home automation systems, smart meters and innovative device for the energy management;

- taking embodied carbon and other embodied impacts (like resources use, water, etc.) into account in the choice of materials and systems in a LCA vision; and

- collaboration with local industry to develop a supply chain for green refurbishment of existing building stock.

These research activities will impact on:

- reduction of total buildings (primary) energy consumption;

- significant reduction of renovation operations and related impacts while ensuring low disruption for users;

- reduction of installation time, thanks to preassembled system adoption compared to a typical renovation process for the building type;

- better quality standard and performance guarantee for the installed prefabricated modules and their integrated components, while enhancing indoor air quality;

- demonstration of the replicability potential;

- pay-back period below 10 years;

- a market of new high-tech SMEs specialized in renovation with prefabricated modules; and

- high-skill jobs for workers that could apply innovative construction tools.

With reference to further development of findings, the integration of technical approach with a deep renovation in the financial schemes and in the governance of the built environment retrofitting initiatives is to be taken into consideration. The further enhancement of the study will be focussed on the design of suitable and replicable models covering from the concept phase to construction process, in order to manage the complexity of the existing building stock and obtain a homogeneous set of key indicators in large-scale interventions.

\section{REFERENCES}

[1] Seppänen, O. \& Goeders, G., Benchmarking regulations on energy efficiency of buildings. Executive summary. Federation of European Heating, Ventilation and Air-conditioning Associations - REHVA, The REHA, European HVAC Journal, 5 May 2010.

[2] Gianfrate, V., Normativa e prodotti edilizi: verso la sostenibilità del costruito, Il Progetto Sostenibile, vol. 32, Edicom Edizioni: Milan, July 2013.

[3] Liddell, C. \& Morris, C., Fuel poverty and human health: a review of recent evidence. Energy Policy, 38, pp. 2987-2997, 2010. doi: http://dx.doi.org/10.1016/j. enpol.2010.01.037

[4] BPIE, European Buildings under the Microscope: A Country-by-Country Review of the Energy Performance of Buildings, BPIE: Brussels, October 2011. 
[5] Saheb, Y., Bodis, K., Szabo, S., Ossenbrink, H. \& Panev, S., European Commission Joint Research Centre Institute for Energy and Transport, Energy Renovation: The Trump Card for the New Start for Europe, Publications Office of the European Union, 2015.

[6] Euroconstruct, 79th Euroconstruct Summary Report, Euroconstruct, 2015.

[7] Pinnegar, S., Marceau, J. \& Randolph, B., Innovation and the City: Challenges for the Built Environment Industry, City Future Research Centre, University of New South Wales, 2008.

[8] Ravetz, J., State of the stock - what do we know about existing buildings and their future prospects? Energy Policy, 36, pp. 4462-2270, 2008. doi: http://dx.doi.org/10.1016/j. enpol.2008.09.026

[9] Dixon, T., Sustainable urban development to 2050: complex transitions in the built environment of cities, In: The Oxford Programme for the Future of Cities , 26th October 2010, Saïd Business School, University of Oxford, 2010.

[10] CIBSE, Climate Change and the Indoor Environment: Impacts and Adaptation; and Beating the Heat, a joint publication by UKCIP Arup and the Department for Trade and Industry, 2005.

[11] Boeri, A., Antonini, E., Gaspari, J. \& Longo, D., Energy Design Strategies for Retrofitting. Methodology, Technologies and Applications, WIT Press: Southampton, 2015.

[12] De Troyer, F., Open industrialisation in building: definition of objectives, concepts an the role of dimensional co-ordination, CIB W24, 22 May, Helsinki, 1995.

[13] Asimakopoulos, D.N., Assimakopoulos, V.D., Chrisomallidou, N., Klitsikas, N., Mangold, D., Michel, P., Santamouris, M. \& Tsangrassoulis, A., Energy and Climate in the Urban Built Environment, James \& James: London, UK, 2001.

[14] Golino, R., Tematiche Nzeb: tra aspetti formali e requisiti prestazionali, Edifici a Energia Quasi Zero - verso il 2020. Il futuro delle costruzioni tra decreti Nzeb, edifici di riferimento, certificazione ed efficienza energetica in area mediterranea, L'Aquila, 13 Maggio 2015, available at: http://www.cottopossagno.com/download/ANDIL\%20 Treviso\%2027mar15.pdf.

[15] REHVA, Assessment of the state of the art of existing technologies to support nZEB renovations, NEZEH Project (IEE) Report, December 2013.

[16] Simonella, A. \& Pau, I. (Arup Facade Engineering), How to design a building envelope to provide thermal comfort and energy efficiency considering climate change, Proceedings of Conference: Adapting to Change: New Thinking on Comfort, Cumberland Lodge, Windsor, UK, 9-11 April 2010. Network for Comfort and Energy Use in Buildings: London.

[17] Antonini, E., Gianfrate, V. \& Longo, D., Towards NZEB: modular pre-assembled steel systems for residential buildings, ed. C.A. Brebbia, Eco-Architecture V 2014, pp. 349359, Wessex Institute, Southampton, UK, 2014.

[18] Azari, R., Modular prefabricated residential construction. Constraints and opportunities, PNCCRE Technical Report, University of Washington, Skanka, USA, 2013.

[19] Tam, Vivian W.Y., Tam, C.M., Zang, S.X. \& William C.Y.Ng., Towards adoption of prefabrication in construction. Building and Environment, 42(10), pp. 3642-3654, 2007. doi: http://dx.doi.org/10.1016/j.buildenv.2006.10.003

[20] Boeri, A. \& Longo, D., Energy efficiency in buildings in southern Europe: challenges and design strategies. International Journal of Sustainable Development and Planning, 6(4), pp. 522-536, 2011. doi: http://dx.doi.org/10.2495/SDP-V6-N4-522-536 
[21] Boeri, A., Gabrielli, L. \& Longo, D., Evaluation and feasibility study of retrofitting interventions on social housing in Italy. Procedia engineering, 21, pp. 1161-1168, 2011. doi: http://dx.doi.org/10.1016/j.proeng.2011.11.2125

[22] Giles, H., Prefabricated construction using digitally integrated industrial manufacturing, The ARCC Journal of Architectural Research, 5(2), pp. 49-65, 2008. doi: http:// dx.doi.org/10.17831/enq:arcc.v5i2.16

[23] Pollo, R., Progetto, durabilità, manutenzione: un metodo per la valutazione della durabilità, Techne, 7, pp. 178-185, 2014.

[24] Quale, J., Eckelman, M.J., Williams, K.W., Sloditskie, G. \& Zimmerman, J.B., Construction matters: comparing environmental impacts of building modular and conventional homes in the United States. Journal of Industrial Ecology, 16(2), pp. 243-253, 2012. doi: http://dx.doi.org/10.1111/j.1530-9290.2011.00424.x

[25] Velik, R. \& Nicolay, P., Energy management in storage-augmented, grid-connected prosumer buildings and neighborhoods using a modified simulated annealing optimization. Computers \& Operations Research, 3, pp. 1-12, 2015.

[26] Dave, M., Varshney, A. \& Graham, P., Assessing the Climate Change Adaptability of Buildings, City Futures Research Centre Faculty of Built Environment, United Nations Environment Programme, UNSW, 2012. 